\author{
P. WANG ${ }^{1}$ \\ S.M. ZAKEERUDDIN ${ }^{1,}$ \\ M. GRÄTZEL ${ }^{1, \square}$ \\ W. KANTLEHNER ${ }^{2}$ \\ J. MEZGER ${ }^{2}$ \\ E.V. STOYANOV ${ }^{2}$ \\ O. SCHERR ${ }^{2}$
}

\section{Novel room temperature ionic liquids of hexaalkyl substituted guanidinium salts for dye-sensitized solar cells}

${ }^{1}$ Laboratory for Photonics and Interfaces, Swiss Federal Institute of Technology, CH 1015, Lausanne, Switzerland

${ }^{2}$ FH Aalen, FB Chemie/Organische Chemie, 73430 Aalen, Germany
Received: 4 September 2003/Accepted: 9 December 2003 Published online: 5 March 2004 • C Springer-Verlag 2004

ABSTRACT A novel family of room temperature ionic liquids, $N, N$-diethyl- $N, N^{\prime}$-dipropyl- $N^{\prime \prime}$-hexyl- $N^{\prime \prime}$-methylguanidinium iodide (SGI) and $N, N, N^{\prime}, N^{\prime}$-tetramethyl- $N^{\prime \prime}, N^{\prime \prime}$-dipentylguanidinium tricyanomethanide (SGTM) were designed and synthesized. Due to the strong charge delocalization on the tricyanomethanide anion and, thus, weaker ion-pairing, SGTM has a lower viscosity than SGI salt that has iodide as an anion. SGI was successfully used as an iodide resource for dye-sensitized nanocrystalline solar cells. The device with a solvent-free, SGI-based electrolyte achieved a 5.9\% power conversion efficiency under an air mass 1.5 incident light of $9.47 \mathrm{~mW} / \mathrm{cm}^{2}$.

PACS 82.45.Gj; 82.45.Vp; 82.47.Jk

\section{Introduction}

Room temperature ionic liquids have attracted growing interest in recent years owing to their unique chemical and physical properties. It is well known that cations like ammonium, phosphonium, sulphonium, pyridinium, pyrrolidinium and imidazolium can form room temperature ionic liquids with a variety of anions [1-4]. Ionic liquids as promising green solvents have been extensively studied for applications such as catalysis, organic synthesis, batteries and photovoltaics due to their chemical and thermal stability, nonflammability, nonvolatility, high ionic conductivity and possible wide electrochemical window. Prototype guanidinium iodide is a solid salt at room temperature due to the planar structure of the cation and the strong ion pairing. However, asymmetric substitution of hydrogen atoms on nitrogen with different alkyl groups has reduced the melting point drastically to form a room temperature ionic liquid (SGI). $N, N, N^{\prime}, N^{\prime}$-tetramethyl- $N^{\prime \prime}, N^{\prime \prime}$ dipentylguanidinium chloride is a solid at room temperature, while its tricyanomethanide salt (SGTM) is a liquid with low viscosity, which can be ascribed to the reduced ionpairing effect due to the strong charge delocalization on the

Fax: $+41-21 / 6934111$

E-mail: shaik.zakeer@epfl.ch; michael.graetzel@epfl.ch tricyanomethanide anion. This is the first time that room temperature ionic liquids with guanidinium as a cation and tricyanomethanide as an anion have been reported. Importantly, SGI can be used aniodide resource for dye-sensitized nanocrystalline solar cells [5-12]. Earlier, hexamethyl substituted guanidinium tricyanomethanide was reported to be a solid at room temperature, and the synthetic procedure used was time consuming, expensive and complicated [13]. Here, we report a simple synthesis of hexaalkyl substituted guanidinium salts starting from cheap materials. While preparing the manuscript, new room temperature ionic liquids based on the tetra-alkyl-dimethylguanidinium cations were reported [14].

\section{$2 \quad$ Experimental \\ $2.1 \quad$ Reagents}

The amphiphilic Z-907 dye $\left[\right.$ cis- $\mathrm{Ru}\left(\mathrm{H}_{2}\right.$ dcbpy) (dnbpy)(NCS $)_{2}$, where the ligand $\mathrm{H}_{2}$ dcbpy is $4,4^{\prime}$-dicarboxylic acid-2, 2'-bipyridine and dnbpy is 4, 4'-dinonyl-2, $2^{\prime}$ bipyridine] was synthesized as described in our previous paper [15] and its chemical structure is shown in Scheme 1. 400-nm-sized $\mathrm{TiO}_{2}$ particles were received as a gift from CCIC (Japan). N-methylbenzimidazole (NMBI) was purchased from Aldrich and recrystallized from diethyl ether. 3-methoxypropionitrile (MPN, Fluka) was distilled before use. Other chemicals were used as received.

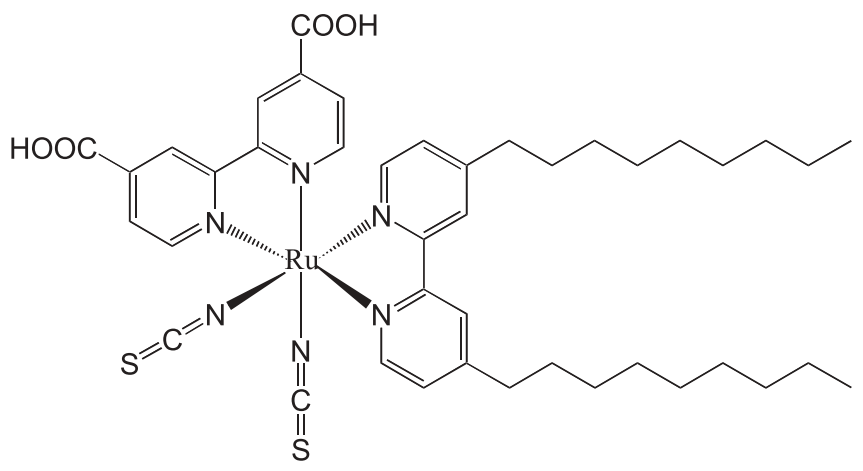

Scheme 1 
To a solution of $106 \mathrm{~g}(1.05 \mathrm{~mol})$ of di- $n$-propyl amine and $106 \mathrm{~g}(1.05 \mathrm{~mol})$ of triethylamine in $500 \mathrm{ml}$ anhydrous acetonitrile, $135.6 \mathrm{~g}(1.0 \mathrm{~mol})$ of $N, N$-diethylcarbamoyl chloride was added drop wise at $-10{ }^{\circ} \mathrm{C}$ and stirred at this temperature for $16 \mathrm{~h}$. The precipitated triethylamine hydrochloride was filtered off and the solvent was evaporated under reduced pressure. The viscous residue was dissolved in $400 \mathrm{ml}$ ether. The solution was kept at $+2{ }^{\circ} \mathrm{C}$ for $16 \mathrm{~h}$. The separated hydrochloride was filtered off and the ether was removed in a rotary evaporator. The $N, N$-diethyl$N^{\prime}, N^{\prime}$-di- $n$-propylurea was obtained by distillation under reduced pressure using a $25 \mathrm{~cm}$ vigreux-columne. Yield: $92 \%$. bp: $106-110^{\circ} \mathrm{C} / 12$ Torr. $n_{\mathrm{D}}^{20}: 1.4496 .{ }^{1} \mathrm{H}$ NMR $\left(\mathrm{CDCl}_{3}\right.$, $250 \mathrm{MHz}) \delta_{\mathrm{H}}: 0.87\left(\mathrm{t}, J=7.4 \mathrm{~Hz}, 6 \mathrm{H}, \mathrm{N}\left(\mathrm{CH}_{2}\right)_{2}-\mathrm{CH}_{3}\right)$, $1.10\left(\mathrm{t}, J=7.1 \mathrm{~Hz}, 6 \mathrm{H}, \mathrm{N}-\mathrm{CH}_{2}-\mathrm{CH}_{3}\right), 1.53(\mathrm{~m}, 4 \mathrm{H}$, $\left.\mathrm{NCH}_{2}-\mathrm{CH}_{2}-\mathrm{CH}_{3}\right), 3.06-3.20\left(\mathrm{~m}, 8 \mathrm{H}, \mathrm{N}-\mathrm{CH}_{2}\right) .{ }^{13} \mathrm{C} \mathrm{NMR}$ $\left(\mathrm{CDCl}_{3}, 62.5 \mathrm{MHz}\right) \delta_{\mathrm{C}}: 11.43,13.26\left(\mathrm{CH}_{3}\right), 21.21\left(\mathrm{~N}_{-} \mathrm{CH}_{2}-\right.$ $\left.\mathrm{CH}_{2}\right), 42.04\left(\mathrm{NCH}_{2}-\mathrm{CH}_{3}\right), 49.92\left(\mathrm{~N}-\mathrm{CH}_{2}-\mathrm{CH}_{2}\right), 165.30$ $\left(\mathbf{C}=\right.$ O). IR (direct, $\left.\mathrm{cm}^{-1}\right)$ : 2963, 2926, $2888\left(\mathrm{CH}_{3}, \mathrm{CH}_{2}\right)$, $1641(\mathrm{C}=\mathrm{O}) . \mathrm{C}_{11} \mathrm{H}_{24} \mathrm{~N}_{2} \mathrm{O}(200.33)$ calc.: $\mathrm{C}, 65.95 ; \mathrm{H}, 12.08$; N, 13.98 (\%). Found: C, 65.63; H, 12.07; N, $14.13(\%)$.

\section{3}

\section{Preparation of} $N$, $N$-diethyl- $N$,' $N^{\prime}$-di-n-propyl- $N^{\prime \prime}$-hexylguanidine

To a solution of $200 \mathrm{~g}$ ( $1.0 \mathrm{~mol}) \mathrm{N}, \mathrm{N}$-diethyl$N^{\prime}, N^{\prime}$-di-n-propylurea in $200 \mathrm{ml}$ anhydrous acetonitrile, $110.0 \mathrm{~g}(1.11 \mathrm{~mol})$ of gaseous phosgene were introduced with stirring at $-5^{\circ} \mathrm{C}$. The reaction mixture was stirred for $6 \mathrm{~h}$ at the same temperature and additionally for $24 \mathrm{~h}$ at $+18^{\circ} \mathrm{C}$. In order to remove the excess of phosgene, $10 \mathrm{ml}$ from the solvent was distilled off under reduced pressure (200 Torr). A mixture of $101 \mathrm{~g}(1.0 \mathrm{~mol})$ hexyl amine and $101 \mathrm{~g}(1.0 \mathrm{~mol})$ of triethylamine was added drop wise so that the reaction mixture began to reflux. After $1 \mathrm{~h}$ at room temperature, the solvent was removed. To the formed mixture of salts was added at $0{ }^{\circ} \mathrm{C}$ with intensive stirring a solution of $40 \mathrm{~g}(1.0 \mathrm{~mol})$ of sodium hydroxide in $100 \mathrm{ml}$ water. The triethylamine and the water were removed by evaporation, and the residue was dissolved in hot acetonitrile $(200 \mathrm{ml})$. The solution was filtered and the filtrate was concentrated under reduced pressure to create the crude product. Then, a solution of $12 \mathrm{~g}$ $(0.3 \mathrm{~mol})$ sodium hydroxide in $100 \mathrm{ml}$ of water was added drop wise at $0{ }^{\circ} \mathrm{C}$ with intensive stirring to a suspension of $32 \mathrm{~g}$ $(0.1 \mathrm{~mol})$ of the crude $N, N$-diethyl- $N^{\prime}, N^{\prime}$-di- $n$-propyl- $N^{\prime \prime}$ hexylguanidinium chloride in $100 \mathrm{ml}$ of diethyl ether. After $20 \mathrm{~min}$, the ether layer was separated and the water phase was extracted with $50 \mathrm{ml}$ diethyl ether once. The combined organic extracts were dried over potassium carbonate for $1 \mathrm{~h}$, the drying agent was filtered off and the solvent was removed. The residue was distilled under reduced pressure using a $25 \mathrm{~cm}$ vigreux-columne. Yield: $81 \%$. bp: $86^{\circ} \mathrm{C} / 10^{-2}$ Torr. $n_{\mathrm{D}}^{20}: 1.4626 .{ }^{1} \mathrm{H}$ NMR $\left(\mathrm{CDCl}_{3}, 250 \mathrm{MHz}\right) \delta_{\mathrm{H}}: 0.80-0.99(\mathrm{~m}$, $\left.9 \mathrm{H}, \mathrm{N}\left[\mathrm{CH}_{2}-\mathrm{CH}_{2}-\mathrm{CH}_{3}\right]_{2}, \mathrm{~N}-\left(\mathrm{CH}_{2}\right)_{5}-\mathrm{CH}_{3}\right), 1.02-1.05(\mathrm{~m}$, $\left.6 \mathrm{H}, \mathrm{N}\left[\mathrm{CH}_{2}-\mathrm{CH}_{3}\right]_{2}\right), 1.29-1.37\left(\mathrm{~m}, 6 \mathrm{H}, \mathrm{N}\left(\mathrm{CH}_{2}\right)_{2}-\left(\mathrm{CH}_{2}\right)_{3}-\right.$ $\left.\mathrm{CH}_{3}\right), 1.40-1.54\left(\mathrm{~m}, 6 \mathrm{H}, \mathrm{N}\left(\mathrm{CH}_{2}\right)-\left(\mathrm{CH}_{2}\right)-\left(\mathrm{CH}_{2}\right)_{3}-\mathrm{CH}_{3}\right.$, $\left.\mathrm{N}\left[\mathrm{CH}_{2}-\mathrm{CH}_{2}-\mathrm{CH}_{3}\right]_{2}\right), 2.88-2.98\left(\mathrm{~m}, 4 \mathrm{H}, \mathrm{N}-\mathrm{CH}_{2}\right), 2.91-$ $3.16\left(\mathrm{~m}, 6 \mathrm{H}, \mathrm{N}-\mathrm{CH}_{2}\right) \cdot{ }^{13} \mathrm{C} \mathrm{NMR}\left(\mathrm{CDCl}_{3}, 62.5 \mathrm{MHz}\right) \delta_{\mathrm{C}}$ : 11.49, 11.61, 12.97, 13.62, $14.12\left(\mathrm{CH}_{3}\right), 20.91,21.73,22.78$,
22.80, 31.91, 31.96, 41.64, 42.54, 49.48, 51.08, $51.13\left(\mathrm{CH}_{2}\right)$, $158.74\left(\mathbf{C N}_{3}\right)$. IR (direct, $\left.\mathrm{cm}^{-1}\right)$ : 2956, 2926, $2855\left(\mathrm{CH}_{3}\right.$, $\left.\mathrm{CH}_{2}\right), 1613(\mathrm{C}=\mathrm{N}) . \mathrm{C}_{17} \mathrm{H}_{37} \mathrm{~N}_{3}(283.50)$ calc.: C, 72.02; $\mathrm{H}$, $3.15 ; \mathrm{N}, 14.82(\%)$. Found: C, 71.03; H, 12.91; N, $15.00(\%)$.

2.4

\section{Preparation of $N$, N-diethyl- $N, N^{\prime}$-di-n-propyl- $N^{\prime \prime}$ - hexyl- $N^{\prime \prime}$-methylguanidinium iodide (SGI)}

$4.3 \mathrm{~g}(0.03 \mathrm{~mol})$ of methyl iodide were added to a stirred solution of $8.5 \mathrm{~g}(0.02 \mathrm{~mol}) \mathrm{N}, N$-diethyl- $N^{\prime}, N^{\prime}$ di- $n$-propyl- $N^{\prime \prime}$-hexylguanidine in $5 \mathrm{ml}$ anhydrous acetonitrile. After stirring at room temperature for $12 \mathrm{~h}$, the excess of methyl iodide and the solvent were removed under reduced pressure. Yield: $96 \% . n_{\mathrm{D}}^{20}: 1.5370 .{ }^{1} \mathrm{H} \mathrm{NMR}\left(\mathrm{CDCl}_{3}\right.$, $250 \mathrm{MHz}) \delta_{\mathrm{H}}: 0.86-1.02\left(\mathrm{~m}, 9 \mathrm{H}, \mathrm{N}\left(\mathrm{CH}_{2}-\mathrm{CH}_{2} \mathrm{CH}_{3}\right)_{2}, \mathrm{~N}-\right.$ $\left.\left(\mathrm{CH}_{2}\right)_{5}-\mathrm{CH}_{3}\right), 1.21-1.34\left(\mathrm{~m}, 12 \mathrm{H}, \mathrm{N}\left(\mathrm{CH}_{2}-\mathrm{CH}_{3}\right)_{2}, \mathrm{~N}-\right.$ $\left.\left(\mathrm{CH}_{2}\right)_{2}-\left(\mathrm{CH}_{2}\right)_{3}-\mathrm{CH}_{3}\right), 1.45-1.77\left(\mathrm{~m}, 6 \mathrm{H}, \mathrm{N}\left(\mathrm{CH}_{2}-\mathrm{CH}_{2}-\right.\right.$ $\left.\mathrm{CH}_{3}\right)_{2}, \mathrm{~N}-\left(\mathrm{CH}_{2}-\mathrm{CH}_{2}-\left(\mathrm{CH}_{2}\right)_{3}-\mathrm{CH}_{3}\right), 2.98-3.46(\mathrm{~m}, 10 \mathrm{H}$, $\mathrm{N}\left(\mathrm{CH}_{2}-\mathrm{CH}_{2}-\mathrm{CH}_{3}\right)_{2}, \mathrm{~N}\left(\mathrm{CH}_{2}-\mathrm{CH}_{3}\right)_{2}, \mathrm{~N}-\mathrm{CH}_{2}-\left(\mathrm{CH}_{2}\right)_{4}-$ $\left.\mathrm{CH}_{3}\right), 3.11\left(\mathrm{~s}, 3 \mathrm{H}, \mathrm{N}-\mathrm{CH}_{3}\right) \cdot{ }^{13} \mathrm{C} \mathrm{NMR}\left(\mathrm{CDCl}_{3}, 62.5 \mathrm{MHz}\right)$ $\delta_{\mathrm{C}}: 11.39,11.53,12.99,13.58,13.93\left(\mathrm{CH}_{3}\right), 21.00,21.33$, $22.51,26.58,27.27,31.30\left(\mathbf{C H}_{2}\right), 39.70\left(\mathrm{~N}-\mathbf{C H}_{3}\right), 44.25$, 51.62, 51.72, 53.20, $53.28\left(\mathrm{CH}_{2}\right), 163.84\left(\mathrm{CN}_{3}\right)$. IR (direct, $\left.\mathrm{cm}^{-1}\right)$ : 2956, 2928, $2865\left(\mathrm{CH}_{3}, \mathrm{CH}_{2}\right), 1534(\mathrm{C}-\mathrm{N})$. $\mathrm{C}_{18} \mathrm{H}_{40} \mathrm{~N}_{3} \mathrm{I}(425.44)$ calc.: C, 50.82; H, 9.48; N, 9.88; I, 29.83 (\%). Found: C, 50.17; H, 9.57; N, 9.64; I, 29.47 (\%).

\section{5}

\section{Preparation of \\ $N, N, N, N^{\prime}$-tetramethyl- $N^{\prime \prime}, N^{\prime \prime}$-dipentylguanidinium tricyanomethanide (SGTM)}

Solutions of $6.5 \mathrm{~g}(0.05 \mathrm{~mol})$ potassium tricyanomethanide [16] in $60 \mathrm{ml}$ acetonitrile and $10.4 \mathrm{~g}(0.03 \mathrm{~mol})$ $N, N, N^{\prime}, N^{\prime}$-tetramethyl- $N^{\prime \prime}, N^{\prime \prime}$-dipentylguanidinium chloride $[17,18]$ in $10 \mathrm{ml}$ acetonitrile were mixed and stirred at room temperature for $18 \mathrm{~h}$. The precipitated potassium chloride was filtered off and the solvent was removed under reduced pressure. To the residue was added $50 \mathrm{ml}$ dichloromethane and kept at $+2{ }^{\circ} \mathrm{C}$ for $16 \mathrm{~h}$. The mixture was filtered and the filtrate was evaporated in a rotary evaporator. Yield: $8.7 \mathrm{~g}(84 \%) \cdot n_{\mathrm{D}}^{20}: 1.4958 .{ }^{1} \mathrm{H} \mathrm{NMR}\left(\mathrm{CDCl}_{3}, 250 \mathrm{MHz}\right)$ $\delta_{\mathrm{H}}: 13.66\left(\mathrm{t}, J=6.8 \mathrm{~Hz}, 6 \mathrm{H}, \mathrm{N}\left[\left(\mathrm{CH}_{2}\right)_{4}-\mathrm{CH}_{3}\right)_{2}\right], 1.22-$ $1.39\left(\mathrm{~m}, 8 \mathrm{H}, \mathrm{N}\left[\left(\mathrm{CH}_{2}\right)_{2}-\left(\mathrm{CH}_{2}\right)_{2}-\mathrm{CH}_{3}\right]_{2}\right), 1.42-1.47(\mathrm{~m}$, $\left.2 \mathrm{H}, \mathrm{N}\left[\left(\mathrm{CH}_{2}\right)-\left(\mathrm{CH}_{2}\right)-\left(\mathrm{CH}_{2}\right)_{2}-\mathrm{CH}_{3}\right]_{2}\right), 1.50-1.67(\mathrm{~m}, 2 \mathrm{H}$, $\left.\mathrm{N}\left[\left(\mathrm{CH}_{2}\right)-\left(\mathrm{CH}_{2}\right)-\left(\mathrm{CH}_{2}\right)_{2}-\mathrm{CH}_{3}\right]_{2}\right), 2.99\left(\mathrm{~s}, 6 \mathrm{H}, \mathrm{N}\left(\mathrm{CH}_{3}\right)_{2}\right)$, $3.02\left(\mathrm{~s}, 6 \mathrm{H}, \mathrm{N}\left(\mathrm{CH}_{3}\right)_{2}\right), 3.06-3.27\left(\mathrm{~m}, 4 \mathrm{H}, \mathrm{N}\left(\mathrm{CH}_{2}-\left(\mathrm{CH}_{2}\right)_{3}-\right.\right.$ $\left.\mathrm{CH}_{3}\right)_{2} \cdot{ }^{13} \mathrm{C} \mathrm{NMR}\left(\mathrm{CDCl}_{3}, 63 \mathrm{MHz}\right) \delta_{\mathrm{C}}: 6.28\left[\mathrm{C}(\mathrm{CN})_{3}\right], 13.91$ $\left(\mathrm{CH}_{3}\right), 22.29,27.40,28.82\left(\mathrm{CH}_{2}\right), 40.40,40.44\left[\mathrm{~N}\left(\mathbf{C H}_{3}\right)_{2}\right]$, $49.81\left(\mathrm{~N}-\mathbf{C H}_{2}\right), 121.79(\mathbf{C} \equiv \mathrm{N}), 163.28\left(\mathbf{C N}_{3}\right)$. IR (direct, $\left.\mathrm{cm}^{-1}\right)$ : 2951, 2931, $2865\left(\mathrm{CH}_{3}, \mathrm{CH}_{2}\right), 2151(\mathrm{C} \equiv \mathrm{N}), 1585$, $1561(\mathrm{C}-\mathrm{N}) . \mathrm{C}_{19} \mathrm{H}_{34} \mathrm{~N}_{6}(346.28)$ calc.: $\mathrm{C}, 65.86 ; \mathrm{H}, 9.89 ; \mathrm{N}$, 24.25(\%). Found: C, 65.77; H, 9.97; N, 23.81 (\%).

\subsection{Viscosity measurements}

Viscosities were measured with an ARES (Advanced Rheometric Expansion System, Rheometrics) rheometer in oscillating shear with parallel plates of $25 \mathrm{~mm}$ in diameter. The thickness of the specimens was about $0.6 \mathrm{~mm}$. The 
oscillating shear measurements were performed in the linear viscoelastic regime as determined from strain sweeps at constant shear rate.

\section{7}

\section{Electrochemical measurements}

A computer controlled Autolab P20 electrochemical workstation (Eco Chimie, Netherlands) was employed for voltammetric measurements. A two-electrode electrochemical cell, consisting of a $5.0 \mu \mathrm{m}$ radius $\mathrm{Pt}$ ultramicroelectrode (Bioanalytical Systems, Inc., USA) as a working electrode and a $\mathrm{Pt}$ foil as a counter electrode, was used for the diffusion coefficient measurements of triiodide and iodide. A CDM210 conductivity meter (Radiometer Analytical, France) was employed to measure the conductivities of our electrolyte at various temperatures. The CDC749 conductivity cell (Radiometer Analytical, France) with a nominal cell constant of $1.70 \mathrm{~cm}^{-1}$ was calibrated with $0.1 \mathrm{M} \mathrm{KCl}$ aqueous solution prior to experiments. A DT Hetotherm cycle heat pump (Heto, Denmark) was used to control the temperature of electrolyte.

\section{8 \\ Fabrication of dye-sensitized solar cells}

A screen-printed double layer of $\mathrm{TiO}_{2}$ particle was used as photoanode. A $10 \mu \mathrm{m}$ thick film of $20 \mathrm{~nm}$ sized $\mathrm{TiO}_{2}$ particles was first printed on the fluorine-doped $\mathrm{SnO}_{2}$ conducting glass electrode and further coated by $4 \mu \mathrm{m}$ thick second layer of $400 \mathrm{~nm}$ light scattering anatase particles. The detailed fabrication procedures for double-layer $\mathrm{TiO}_{2}$ nanocrystalline photoanodes and solar cells were described in our previous work [19]. The $\mathrm{TiO}_{2}$ electrodes were sensitized by immersing them into a dye solution consisting of $0.3 \mathrm{mM}$ Z-907 dye in acetonitrile and $t$-butanol (volume ratio: $1: 1$ ) at room temperature for $12 \mathrm{~h}$. The electrodes were separated by a $35 \mu \mathrm{m}$ thick Bynel hot-melt ring (DuPont, USA) and sealed up by heating. The internal space was filled with electrolyte using a vacuum pump to produce device $A$ and $B$ with electrolytes A and B, respectively. Electrolyte A contains $0.5 \mathrm{M}$ $\mathrm{N}$-methyl-benzimidazole (NMBI) and $0.5 \mathrm{M} \mathrm{I}_{2}$ in SGI. Electrolyte B is composed of $0.6 \mathrm{M} \mathrm{SGI}, 0.5 \mathrm{M}$ NMBI and $0.1 \mathrm{M}$ $\mathrm{I}_{2}$ in 3-methoxypropionitrile (MPN). In these electrolytes, NMBI is used as base. Additionally, electrolyte B is mainly based on organic solvent, and SGI is used as iodide resource. It should be noted that the added iodine would react with the excess iodide to form triiodide. The cells with electrolytes A and $\mathrm{B}$ are denoted as device $\mathrm{A}$ and $\mathrm{B}$, respectively.

\section{9}

\section{Photoelectrochemical measurements}

A $450 \mathrm{~W}$ xenon light source (Oriel, USA) was used to give an irradiance of $100 \mathrm{~mW} \mathrm{~cm}^{-2}$ (the equivalent of one sun at AM 1.5) at the surface of solar cells. The spectral output of the lamp was matched in the region of 350-750 $\mathrm{nm}$ with the aid of a Schott K113 Tempax sunlight filter (Präzisions Glas \& Optik GmbH, Germany), so as to reduce the mismatch between the simulated and the true solar spectrum to less than $2 \%$. Various incident light intensities were regulated with neutral wire mesh attenuators. The current-voltage characteristics of the cell under these conditions were obtained by applying external potential bias to the cell and measuring the generated photocurrent with a Keithley model 2400 digital source meter (Keithley, USA). This process was fully automated using Wavemetrics software ( http://www.wavemetrics.com/).

\section{Results and discussions}

\section{Synthesis}

The synthesis of $N, N$-diethyl- $N^{\prime}, N^{\prime}$-dipropyl$N^{\prime \prime}$-hexyl- $N^{\prime \prime}$-methylguanidinium iodide (4, SGI) is described in Scheme 2 and $N, N, N^{\prime}, N^{\prime}$-tetramethyl- $N^{\prime \prime}, N^{\prime \prime}$ dipentylguanidinium tricyanomethanide (SGTM, Scheme 3) was prepared by anion exchange reaction of $N, N, N^{\prime}, N^{\prime}-$ tetramethyl- $N^{\prime \prime}, N^{\prime \prime}$-dipentylguanidinium chloride with potassium tricyanomethanide.

\subsection{Viscosity}

The electrostatic attraction force between cations and anions, the steric packing of ions, the tendency to form hydrogen bonding and the strength of Van der Waals interaction essentially determine the viscosity of ionic liquids. In the case of the ionic liquid SGI, asymmetric substitution of the protons on the nitrogen of the guanidinium iodide with different alkyl groups results in a room temperature ionic liquid with viscosity of $3330 \mathrm{cPs}$, which is likely caused by destabilization of the crystalline state. The viscosity of ionic liquid also depends on the charge densities of ions, which determine the strength of electrostatic attraction force between anions and cations. $N, N, N^{\prime}, N^{\prime}$-tetramethyl$N^{\prime \prime}, N^{\prime \prime}$-dipentylguanidinium chloride is a solid due to strong ion-pairing. Replacing the chloride with tricyanomethanide anion, which has a very low negative charge density due to delocalisation over three cyanide groups, forms a less viscous ionic liquid with a viscosity of $88 \mathrm{cPs}$. Even though the cation

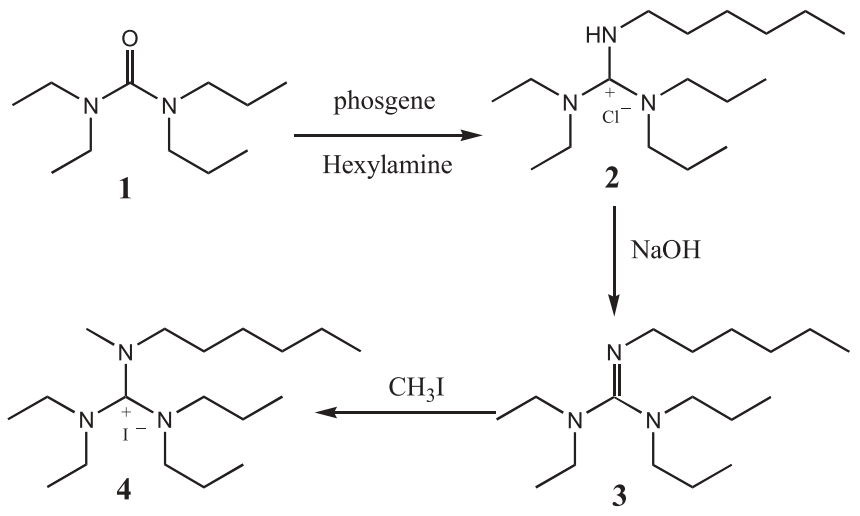

Scheme 2

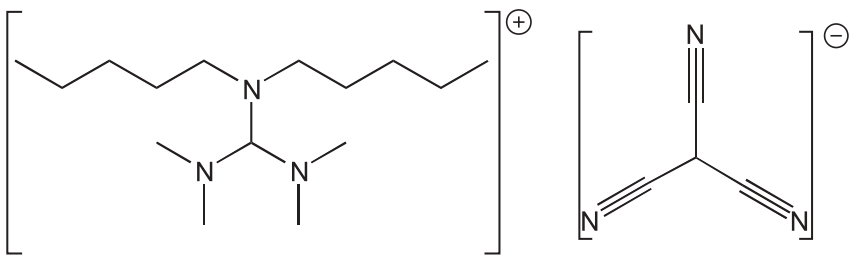

Scheme 3 
is not exactly same in case of SGI and SGTM, the viscosity decreases from $3330 \mathrm{cPs}$ to $88 \mathrm{cPs}$ by changing the anions from iodide to tricyanomethanide. The tricyanomethanide ion has a lower negative charge density compared with iodide in reducing the coulombic interactions with the guanidinium cation. It is interesting that ionic liquids having relatively low viscosity can be prepared from guanidinium cations and tricyanomethanide anions.

\subsection{Conductivity}

The conductivity $(\sigma)$ of pure SGI and solventfree electrolyte A was first examined. It provides information on the mobility of the ions and ion-pairing phenomenon, which are expected to influence the photovoltaic performance and in particular the fill factor of the solar cell. Mechanistically, when an ionic transport process involves an intermolecular ion hopping, the conductivity will be determined by the thermal hopping frequency, which leads to an Arrhenius conductivity-temperature behaviour. As is apparent from the inset of Fig. 1, the Arrhenius equation cannot be used to describe the conductivity-temperature behaviour of the electrolyte. A better fit to the data (Fig. 1) is obtained by the Vogel-Tammann-Fulcher (VTF) equation [20].

$\sigma(T)=A T^{-1 / 2} \exp \left[-B /\left(T-T_{0}\right)\right]$

In (1), $A$ and $B$ are constants; $T$ is the absolute temperature, while $T_{0}$ is the glass-transition temperature. The VTF conductivity-temperature behaviour indicates there is still a strong ion pairing in pure SGI and electrolyte A. The higher conductivity of electrolyte A than pure SGI at low temperature is due to less ion pairing since the negative charge density of triiodide is lower compared with iodide. However, the conductivity difference between SGI and electrolyte A becomes less at high temperature, indicating a higher freedom of ions in pure SGI as the temperature increases.

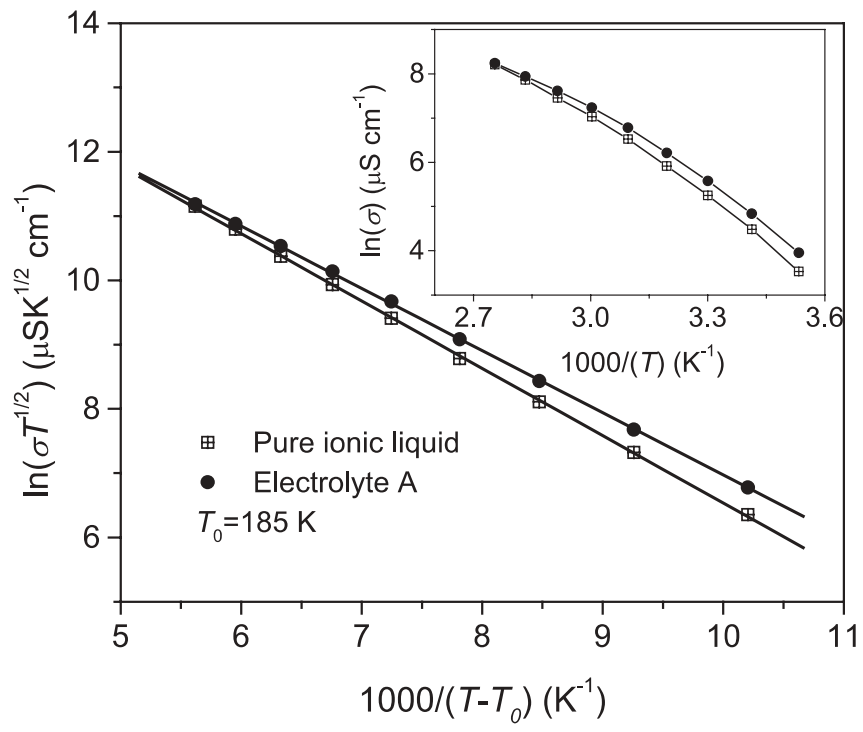

FIGURE 1 Plots of conductivity-temperature data in the VTF coordinates for pure SGI and electrolyte A. The inset is Arrhenius plots of conductivitytemperature data

\section{4}

\section{Photovoltaic measurements}

Figure 2 presents typical photocurrent densityvoltage curves under simulated air mass (AM) 1.5 sunlight illumination. At an intensity of $1.47 \mathrm{~mW} / \mathrm{cm}^{2}$, device A with solvent-free ionic liquid electrolyte has a short-circuit photocurrent density $\left(J_{\mathrm{sc}}\right)$ of $0.244 \mathrm{~mA} / \mathrm{cm}^{2}$, open-circuit voltage $\left(V_{\mathrm{oc}}\right)$ of $670 \mathrm{mV}$, fill factor $(f f)$ of 0.73 , and an overall energy conversion efficiency $(\eta)$ of $7.4 \%$. The corresponding device parameters $\left(J_{\mathrm{sc}}, V_{\mathrm{oc}}, f f\right.$, and $\left.\eta\right)$ under an irradiance of $9.47 \mathrm{~mW} / \mathrm{cm}^{2}$ are $1.26 \mathrm{~mA} / \mathrm{cm}^{2}, 710 \mathrm{mV}, 0.628$, and $5.9 \%$, respectively. However, if the intensity exceeds $50 \mathrm{~mW} / \mathrm{cm}^{2}$, the conversion efficiency of the device declines due to mass transport limitations. Thus, the photocurrent response of device A depends in a nonlinear fashion on the light intensity that is caused by the high viscosity of SGI, reducing the triiodide diffusion coefficient. Photovoltaic parameters $\left(J_{\mathrm{sc}}, V_{\mathrm{oc}}, F F\right.$, and $\left.\eta\right)$ for device B at an irradiance of $100 \mathrm{~mW} / \mathrm{cm}^{2}$ are $13.1 \mathrm{~mA} / \mathrm{cm}^{2}, 747 \mathrm{mV}, 0.63$, and $6.2 \%$. Efficiencies of device B under sunlight of 10 and $50 \mathrm{~mW} / \mathrm{cm}^{2}$ are 7.4 and $7 \%$, respectively. Thus, the performance of device $\mathrm{B}$ is similar to that of a solar cell [15] based on a similar electrolyte containing 1,2-dimethyl-3-propylimidazolium iodide instead of SGI.

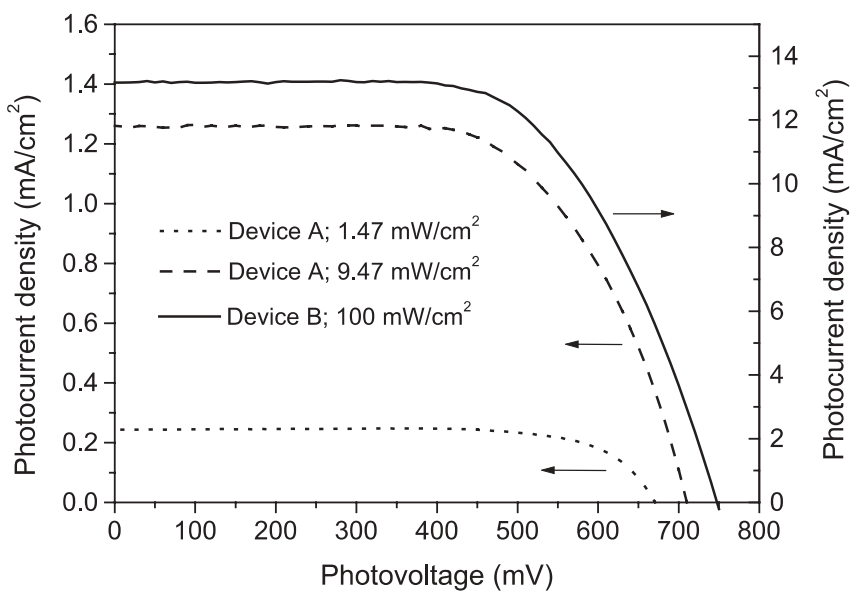

FIGURE 2 Photocurrent density-voltage characteristics of device A and B at different incident light intensities. Cell active area: $0.152 \mathrm{~cm}^{2}$

\section{Diffusion and its implication to device performance}

Diffusion of iodide and triiodide in electrolytes $\mathrm{A}$ and $\mathrm{B}$ were measured to reveal the limiting step of devices $\mathrm{A}$ and $\mathrm{B}$ at room temperature. The steady-state voltammograms of electrolytes $\mathrm{A}$ and $\mathrm{B}$ at the scan rate of $10 \mathrm{mV} / \mathrm{s}$ are shown in Fig. 3. The apparent diffusion coefficients $\left(D_{\text {app }}\right)$ of iodide and triiodide can be calculated from anodic and cathodic steady-state currents $\left(I_{\mathrm{sS}}\right)$ according to the following equation $[21,22]$.

$I_{\mathrm{ss}}=4 n c a F D_{\mathrm{app}}$

Where $n$ is the electron transfer number per molecule, $F$ is the Faraday constant and $c$ is the bulk concentration of electroactive species. The calculated diffusion coefficients of triiodide and iodide in electrolyte A are $3.8 \times 10^{-8}$ and 


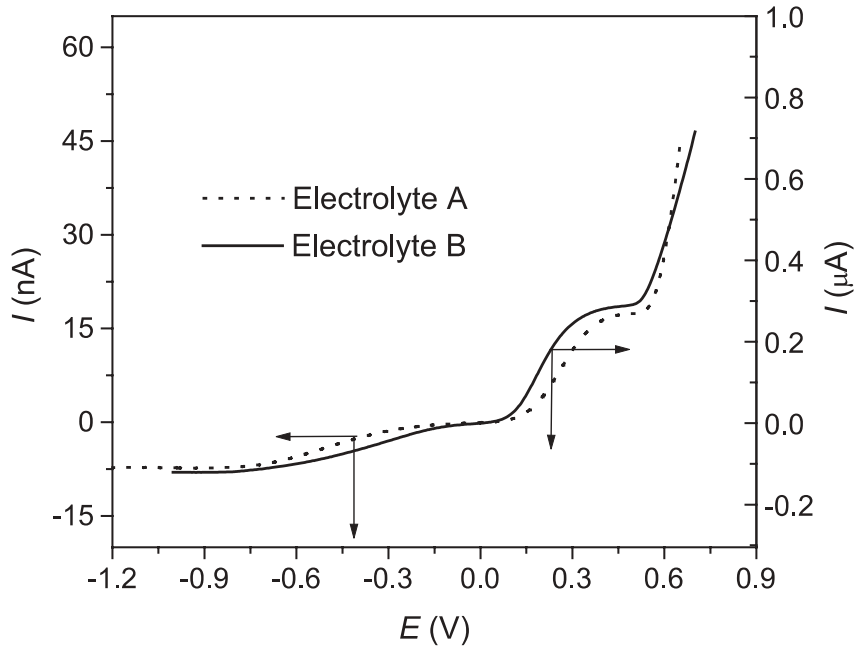

FIGURE 3 Steady-state voltammograms for a Pt ultramicroelectrode in electrolyte A and B. Scan rate: $10 \mathrm{mV} / \mathrm{s}$

$6.9 \times 10^{-8} \mathrm{~cm}^{2} \mathrm{~s}^{-1}$, respectively, which are about five times lower than in solvent-free, 1-mehtyl-3-propylimidazolium iodide based ionic liquid electrolyte [10]. Furthermore, the possible limiting photocurrent density $\left(J_{\text {lim }}\right)$ in device A with this electrolyte can be derived by (3) to be $5 \mathrm{~mA} / \mathrm{cm}^{2}$.

$J_{\lim }=6 \varepsilon_{\mathrm{p}} F D c \frac{1+\frac{b}{\varepsilon_{\mathrm{p}} l}}{\left[1+3 \varepsilon_{\mathrm{p}} \frac{b}{l}+1.5\left(\frac{b}{l}\right)^{2}\right] \times l}$

where $D$ and $c$ are the diffusion coefficient and concentration of triiodide; $\varepsilon_{\mathrm{p}}$ and $b$ are the porosity (63\%) and thickness of nanocrystalline film $(10 \mu \mathrm{m}) ; l$ is the electrolyte thickness $(10 \mu \mathrm{m})$ from photoanode to counter electrode [23]. Thus, we believe that the poor performance of device A at high light intensities is due to the slow diffusion of triiodide in electrolyte A. On the other hand, the calculated diffusion coefficients of triiodide and iodide in electrolyte $\mathrm{B}$ are $2.5 \times 10^{-6}$ and $5.8 \times 10^{-6} \mathrm{~cm}^{2} \mathrm{~s}^{-1}$, respectively. Thus, the fast diffusion of triiodide in electrolyte $\mathrm{B}$ allows for a limiting photocurrent density of $65.8 \mathrm{~mA} / \mathrm{cm}^{2}$. However, the dependence of $J_{s c}$ of device $\mathrm{B}$ on incident photon intensity is still not linear, indicating that its limiting step is due to dye regeneration or photo-induced electron injection rather than the diffusion of triiodide in electrolyte B $[12,15]$.

4

\section{Conclusions}

In summary, novel room temperature ionic liquids, $N, N$-diethyl- $N^{\prime}, N^{\prime}$-dipropyl- $N^{\prime \prime}$-hexyl- $N^{\prime \prime}$-methylguanidinium iodide (SGI) and $N, N, N^{\prime}, N^{\prime}$-tetramethyl- $N^{\prime \prime}, N^{\prime \prime}$ dipentylguanidinium tricyanomethanide (SGTM), have been designed and synthesized. By introducing more delocalized tricyanomethanide anion, the viscosity of SGTM is 38 times larger than SGI. Devices with solvent-free, ionic liquid electrolyte yielded $5.9 \%$ power conversion efficiency under an air mass 1.5 incident light of $9.47 \mathrm{~mW} / \mathrm{cm}^{2}$. The slow diffusion of triiodide in solvent-free, SGI-based electrolyte was proposed as the limiting step for high power application. Furthermore, the organic solvent-based electrolyte containing SGI as iodide resource gave a good photovoltaic performance as that obtained with an imidazolium salt. Its non-linear photovoltaic behaviour may be related to the kinetics of dye regeneration or photo-induced electron injection. Further studies are underway to understand the effect of electrolyte composition on device efficiencies and, thus, to design new guanidinium ionic liquids with lower hydrodynamic viscosity for better device performance.

ACKNOWLEDGEMENTS We are grateful to the Swiss National Science Foundation and the European Office of U.S. Air Force for financial support under Contract No. F61775-00-C0003 and to Marlene Rodlert (LTC, EPFL) for the viscosity measurements.

\section{REFERENCES}

1 T. Welton: Chem. Rev. 99, 2071 (1999)

2 P. Wasserscheid, W. Keim: Angew. Chem. Int. Ed. 39, 3773 (2000)

3 R. Sheldon: Chem. Commun., 2399 (2001)

4 J. Dupont, R.F. De Souza, P.A.Z. Suarez: Chem. Rev. 102, 3667 (2002)

5 B. O’Regan, M. Grätzel: Nature 353, 737 (1991)

6 M. Grätzel: Nature 414, 338 (2001)

7 N. Papageorgiou, Y. Athanassov, M. Armand, P. Bonhôte, H. Pettersson, A. Azam, M. Grätzel: J. Electrochem. Soc. 143, 3099 (1996)

8 H. Matsumoto, T. Matsuda, T. Tsuda, R. Hagiwara, Y. Ito, Y. Miyazaki: Chem. Phys. Lett. 26 (2001)

9 W. Kubo, T. Kitamura, K. Hanabusa, Y. Wada, S. Yanagida: Chem. Commun. 374 (2002)

10 P. Wang, S.M. Zakeeruddin, P. Comte, I. Exnar, M. Grätzel: J. Am. Chem. Soc. 125, 1166 (2003)

11 S. Murai, S. Mikoshiba, H. Sumino, T. Kato, S. Hayase: Chem. Commun. 1534 (2003)

12 P. Wang, S.M. Zakeeruddin, J.E. Moser, M. Grätzel: J. Phys. Chem. B 107, 13280 (2003)

13 Y.A. Pentin, D.I. Makhon'kov, L.Y. D’yachkova, I.I. Baburina, N.S. Zefirov: Zh. Obshch. Khim 48, 1850 (1978)

14 N.M.M. Mateus, L.C. Branco, N.M.T. Lourenço, C.A.M. Afonso: Green. Chem. 5, 347 (2003).

15 P. Wang, S.M. Zakeeruddin, J.E. Moser, M.K. Nazeeruddin, T. Sekiguchi, M. Grätzel: Nat. Mater. 2, 402 (2003)

16 J. Falbe: Methoden der Organischen Chemie (Georg Thieme Verlag, Stuttgart 1985)

17 W. Kantlehner, E. Haug, W.W. Mergen, P. Speh, T. Maier, J.J. Kapassakalidis, H.-J. Bräuner: Synthesis (Stuttgart), 904 (1983)

18 W. Kantlehner, E. Haug, W.W. Mergen, P. Speh, T. Maier, J.J. Kapassakalidis, H.-J. Bräuner und H. Hagen: Liebigs Ann. Chem. 108 (1984)

19 P. Wang, S.M. Zakeeruddin, P. Comte, R. Charvet, R. Humphry-Baker, M. Grätzel, M: J. Phys. Chem. B 107, 14336 (2003)

20 G.Y. Gu, S. Bouvier, C. Wu, R. Laura, M. Rzeznik, K.M. Abraham: Electrochim. Acta 45, 3127 (2000)

21 P. Wang, S.M. Zakeeruddin, I. Exnar, M. Grätzel: J. Chem. Soc., Chem. Commun. 2972 (2002)

22 R. Kawano, M. Watanabe: Chem. Commun. 330 (2003)

23 N. Papageorgiou, M. Grätzel, P.P. Infelta: Sol. Energy Mater. Sol. Cells 44, 405 (1996) 